\title{
Pythium, Phytophthora, and Phytopythium spp. Associated with Soybean in Minnesota, Their Relative Aggressiveness on Soybean and Corn, and Their Sensitivity to Seed Treatment Fungicides
}

\author{
L. Radmer, G. Anderson, D. M. Malvick, and J. E. Kurle, Department of Plant Pathology, University of Minnesota, St. Paul, and \\ A. Rendahl and A. Mallik, School of Statistics, University of Minnesota, Minneapolis
}

\begin{abstract}
Pythium spp. cause seed decay, damping-off, and root rot in soybean and corn; however, their diversity and importance as pathogens in Minnesota are unknown. Our objectives were to identify the Pythium spp. present in Minnesota soybean fields, determine their aggressiveness on corn and soybean, and investigate their sensitivity to seed treatment fungicides. For identification, sequences obtained using internal transcribed space ITS4 and ITS1 primers were compared with reference sequences in the National Center for Biotechnology Information database. Seedling and soil samples yielded over 30 oomycete species. Aggressiveness was determined using two methods; a seed assay, which also examined temperature effects on aggressiveness, and a seedling assay. Of 21 species

evaluated, seven Pythium spp. were pathogenic on both soybean and corn, reducing root growth by $20 \%$ or more while two Pythium and one Phytopythium spp. were pathogenic only on soybean. Aggressiveness of many isolates increased as temperature increased from $15^{\circ} \mathrm{C}$ to $25^{\circ} \mathrm{C}$. The sensitivity of 10 pathogenic species to azoxystrobin, ethaboxam, mefenoxam, pyraclostrobin, or trifloxystrobin was tested. $\mathrm{EC}_{50}$ values for mefenoxam and ethaboxam were $10^{-2}$ of those to strobilurin fungicides. Pythium spp. in Minnesota are diverse and a significant cause of seedling disease on soybean and corn. Most Pythium spp. isolated in this study were more sensitive to mefenoxam and ethaboxam than to strobilurin fungicides.
\end{abstract}

The oomycete Pythium is a major cause of seed and seedling rots in soybean (Glycine max (L.) Merr) and corn (Zea mays L.), two crops often grown in rotation in the Midwestern United States. In soybean, Pythium seed, seedling, and root rots are considered to be among the most important sources of yield loss (Wrather and Koenning 2009; Wrather et al. 2001, 2003). Pythium causes preand postemergence damping-off in both soybean and corn and is considered to be more damaging in cool, damp conditions (Griffin 1990; Rizvi and Yang 1996). In both soybean and corn, infection by Pythium is characterized by lesions on roots and pre and postemergence damping-off of seedlings (Broders et al. 2007, 2009). Plants with nonlethal infections but damaged root systems have decreased vigor and, as a result, reduced yield (Holbert et al. 1923; Rothrock et al. 2015; Sprangue 1943).

In Minnesota, edaphic factors and climatic conditions combine with planting practices to favor infection by Pythium spp. In soybean growing areas, poorly drained clay soils are common. These soils dry slowly and the extra moisture associated with saturated conditions increases their heat capacity, slowing warmup in the spring. In flooded conditions, Pythium can be recovered more frequently than other soil fungi (Kirkpatrick et al. 2006). In addition, crop management practices emphasizing reduced tillage and maintenance of crop residue cover exacerbate the effect of edaphic and environmental factors and further increase the likelihood of seed and seedling infection by Pythium spp. This places the seed in the ground under the most "at risk" conditions. More than 20 Pythium spp. have been confirmed as pathogens in Ohio and Iowa (Broders et al. 2007, 2009; Dorrance et al. 2004; Ellis et al. 2012; Murillo-Williams and Pedersen 2008; Yang and Feng 2001). Although the number of Pythium spp. isolated and identified in the North Central states has increased dramatically, $P$. irregulare, $P$. ultimum var. sporangiiferum, $P$. ultimum var.

Corresponding author: J. E. Kurle; E-mail: kurle001@umn.edu

Accepted for publication 27 July 2016.

() 2017 The American Phytopathological Society ultimum, and $P$. sylvaticum remain the most damaging as pathogens of seeds and seedlings in both corn and soybean (Broders et al. 2007, 2009; Dorrance et al. 2004; Jiang et al. 2012; Wei et al. 2011).

Research on Pythium spp. present in Minnesota that are pathogenic to soybean is limited and outdated. The last published survey, which was conducted in 1965 (Brown and Kennedy 1965), reported three Pythium spp.; P. ultimum, a Pythium sp. similar to P. ultimum but without sexual structures, and an unidentified Pythium isolate, as pathogens on soybean. Recent research conducted in neighboring North Central states has documented a much larger, more diverse community of Pythium spp. infecting soybean (Broders et al. 2007; Jiang et al. 2012; Marchand et al. 2014; Zitnick-Anderson and Nelson 2014). In Iowa, Zhang and Yang (2000) tested the aggressiveness of isolates collected in corn and soybean fields and found that many of the isolates were pathogenic on both corn and soybean; however, they did not identify the individual Pythium spp. responsible. Broders et al. (2007) identified six Pythium spp. pathogenic to corn and nine to soybean in Ohio. Zitnick-Anderson and Nelson (2014) reported 26 described Pythium spp. and three unidentified Pythium spp. in results from a statewide survey conducted over 2 years in North Dakota. In that survey P. ultimum, P. heterothallicum, and an unknown Pythium sp. made up more than $49 \%$ of the isolates. Matthiesen et al. (2015) investigated the effect of temperature on species prevalence and aggressiveness in Iowa. They found P. torulosum to be the predominant Pythium sp. present in corn at lower temperatures $\left(13^{\circ} \mathrm{C}\right)$ but that various other Pythium spp. were favored by higher temperatures $\left(18\right.$ and $\left.20^{\circ} \mathrm{C}\right)$ indicating that the aggressiveness of Pythium is an interaction of species with temperature. These studies also confirmed that many of the Pythium spp. isolated can be pathogens of both corn and soybean (Broders et al. 2007; Hooker 1956; Johann et al. 1928; Rao et al. 1978; Robertson and Ahmad 2013; Rosso et al. 2008; Yanar et al. 1997; Zitnick-Anderson and Nelson 2014).

Management of seedling diseases caused by Pythium spp. has relied on the use of seed treatment fungicides metalaxyl and mefenoxam (Syngenta, Basel, Switzerland). Formerly limited to use with seed corn, the practice of treating seeds with fungicides has recently become commonplace for control of seedling diseases of soybean. For instance, in Minnesota, metalaxyl has been a common seed coating on corn for 
the last 15 to 20 years but it is only in the last decade that seed treatments on soybean have become the norm rather than the exception (D. M. Malvick, personal communication). The strobilurins, azoxystrobin, trifloxystrobin, and pyraclostrobin, are broad-spectrum fungicides frequently applied as seed treatments to control seed and seedling diseases and root rots caused by true fungi. Mefenoxam, the active isomer of metalaxyl, and the recently introduced fungicide, ethaboxam, are effective seed treatment compounds for controlling oomycete pathogens of both corn and soybean. Continued use of metalaxyl and mefenoxam for control of Pythium has resulted in insensitivity of some Pythium spp. to these fungicides in some cropping systems (Brantner and Windels 1998; Cohen and Coffey 1986; Cook and Zhang 1985; Weiland et al. 2014; White et al. 1988). In Minnesota considerable variability in sensitivity has been reported among isolates of $P$. ultimum var. sporangiferum and $P$. aphanidermatum infecting sugar beet (Brantner and Windels 1998); however, there is little information available on the sensitivity to seed treatment fungicides of Pythium spp. pathogenic on soybean. In Ohio, Broders et al. (2007) determined that Pythium spp. with globose sporangia were more sensitive than those with filamentous sporangia to strobilurins, however, the reverse was true with mefenoxam. Moorman et al. (2002) examined the mefenoxam sensitivity of several Pythium spp. isolated from floriculture greenhouses in Pennsylvania and found $37 \%$ of $P$. irregulare isolates were resistant to metalaxyl or mefenoxam $\left(\mathrm{EC}_{50}>\right.$ $100 \mu \mathrm{g}$ a.i./ml). The sensitivity to seed treatment fungicides of Pythium populations found in Minnesota soybean fields is unknown.

The objectives of this research were to (i) isolate and identify Pythium spp. associated with soybean and corn rotations in Minnesota, (ii) evaluate the pathogenicity of the Pythium isolates collected as the cause of seed rots, seedling rots, and damping-off of soybean and corn under a range of temperature conditions, and (iii) evaluate the isolates' sensitivity to seed treatment fungicides in an in vitro assay.

\section{Materials and Methods}

Pythium isolates were recovered from either soil or seedling samples collected from 46 soybean fields throughout Minnesota (Fig. 1). Isolates of Pythium spp. from seedlings in Minnesota were selected from a large collection in part based on preliminary identification done at Michigan State University (Rojas et al. 2013). Identities of all isolates from seedling and soil samples used in this study were determined at the University of Minnesota based on amplification and sequencing of COX1 and internal transcribed space ITS regions.

Collection of seedling and soil samples. During June 2011 and 2012, 25 soybean seedlings were collected from 12 production fields (six each year) located in eight counties in Minnesota (Fig. 1). Fields were chosen based on geographic distribution and disease symptoms or reduced plant stands present in those years or in previous years. Seedlings were sampled from fields at approximately $5 \mathrm{~m}$ intervals along a $250 \mathrm{~m}$ transect laid out in a $\mathrm{W}$ or $\mathrm{Z}$ pattern. Most of the seedlings had necrotic lesions on the roots, although some roots that yielded Pythium isolates had no symptoms. Samples were refrigerated and processed within $72 \mathrm{~h}$ of collection.

Soil samples were collected in eight counties from 37 different soybean production fields with a history of seedling, root and stem rots, or with a history of stand establishment problems. In the fall of 2012 and 2013 (Fig. 1), prior to harvest, 10 separate soil samples approximately 1 liter in total volume were collected within the planted row from every other row on an $\mathrm{X}$ transect centered on an area 7.62 by $53.4 \mathrm{~m}^{2}$ in each field. The soil samples were dried in a forced air drier at $38^{\circ} \mathrm{C}$, for 4 days, ground to pass through $2 \mathrm{~mm}$ openings in a Humboldt Soil Grinder (Humboldt Scientific, Elgin, IL), and stored at room temperature until use.

Isolation from seedlings. Seedlings were washed under running tap water for $30 \mathrm{~min}$ and three 0.5 to $1 \mathrm{~cm}$ sections were cut from each root with a sterile scalpel: one at the root tip, one in either the middle of the root or at a symptomatic area along the length of the root, and one at the hypocotyl/soil interface. Sections were blotted dry and embedded in corn meal agar (CMA) PARPB media (Jeffers and Martin 1986) and then incubated in darkness at $20^{\circ} \mathrm{C}$ for 1 to 7 days until hyphae emerged. Hyphae were examined microscopically and those with characteristics of Pythium were transferred to CMA and stored at $4^{\circ} \mathrm{C}$.
Isolation from soil. Pythium spp. were isolated from soil samples according to the method of Dorrance et al. (2004). Three $10.2 \mathrm{~cm}$ pots were filled with a ground soil sample, saturated with water, and placed in a plastic tray containing water for $24 \mathrm{~h}$, and allowed to drain for $24 \mathrm{~h}$. Pots were then placed in a sealed plastic bag and incubated at room temperature for 2 weeks. Five seeds of soybean cultivar McCall were planted per pot and the pots were placed in a dark $13^{\circ} \mathrm{C}$ growth chamber where the soil was saturated with water every $24 \mathrm{~h}$ over a 5-day period. The seeds were then retrieved from the soil, washed, cut in half, and placed on PIBNC media selective for oomycetes (Broders et al. 2007; Schmitthenner and Bhat 1994). Colonies suspected to be Pythium spp. were transferred to CMA, examined under a microscope to ascertain their genus, and maintained on CMA at $4^{\circ} \mathrm{C}$.

Identification of species. All isolates were identified to species using DNA sequencing techniques. Isolates of Pythium spp. from seedlings in Minnesota were selected from a large collection in part based on preliminary identification done at Michigan State University (Rojas et al. 2013). Identities of all isolates from seedling and soil samples used in this study were determined at the University of Minnesota based on amplification and sequencing of COX1 and ITS regions. Isolates from storage were grown on $10 \%$ clarified V8 liquid media at $20^{\circ} \mathrm{C}$ for up to 1 week. Hyphal mats were collected on a fine sieve, washed with deionized water, blotted dry, and frozen with liquid nitrogen. DNA was extracted with a DNeasy Plant Mini Kit (Qiagen Inc., Valencia, CA) after grinding with a Precellys 24 bead mill homogenizer (MoBio, Carlsbad, CA) and $50 \mu$ l of buffer was used to elute the sample. Amplification of the ITS1, ITS2, and part of the 28S region was accomplished in a $25 \mu \mathrm{l}$ reaction with GoTaq Green Master Mix (Promega, Madison, WI) with primers ITS1 and ITS4 (White et al. 1990). Amplification of the Coxl gene was done with the primers OomCox1Levup and Fm85mod although OomCox1Levlo was used as an alternative reverse primer when needed (Robideau et al. 2011). Amplifications were conducted with an Eppendorf Mastercycler Pro (Eppendorf, Hauppauge, NY) using an initial denaturation step at $95^{\circ} \mathrm{C}$ for 2 min followed by 35 cycles of $95^{\circ} \mathrm{C}$ for $30 \mathrm{~s}, 54^{\circ} \mathrm{C}$

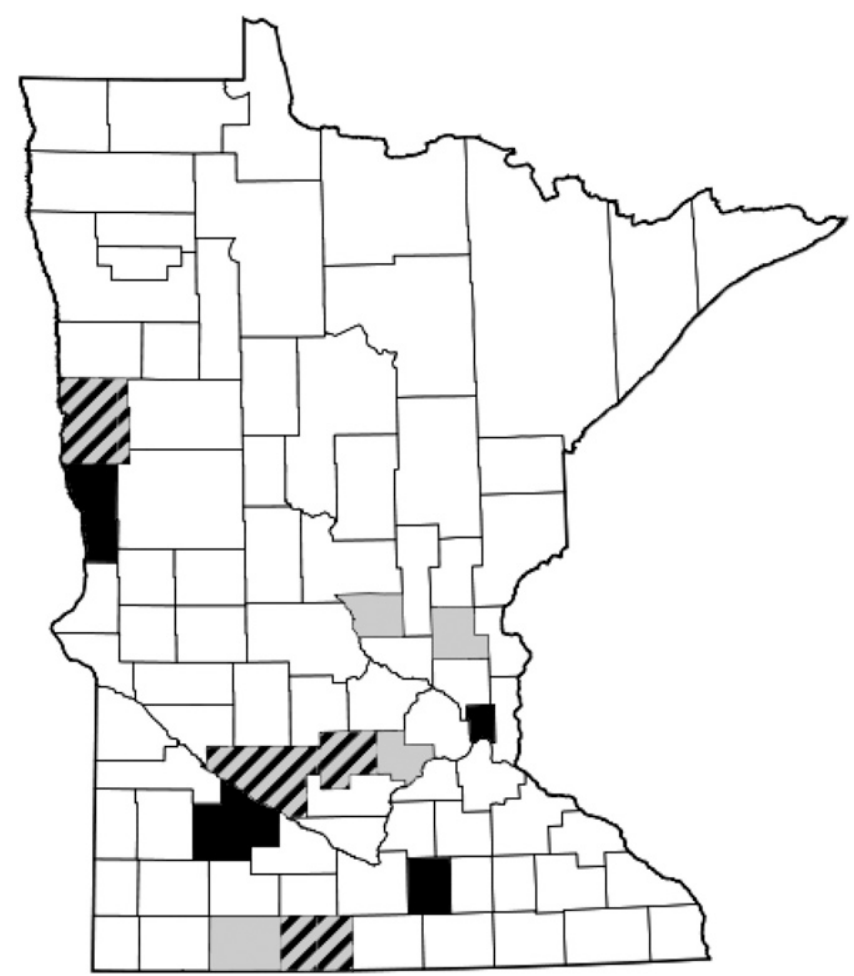

Fig. 1. Counties in Minnesota where isolates used in this study originate. The counties in gray were the sources of isolates retrieved by baiting soil collected in soybean fields. Counties in black were the sources of isolates retrieved from seedling tissue. The counties in a striped pattern were the source of multiple isolates retrieved by either of those techniques. 
(ITS) or $51^{\circ} \mathrm{C}(\operatorname{Cox} 1)$ for $30 \mathrm{~s}$, and $72^{\circ} \mathrm{C}$ for $1 \mathrm{~min}$ and followed by a final extension step at $72^{\circ} \mathrm{C}$ for $5 \mathrm{~min}$ and a final hold at $10^{\circ} \mathrm{C}$. The product underwent electrophoresis on a gel containing $1 \%$ GenePure LE Agarose (ISC BioExpress, Kaysville, UT) which was then stained with SYBR Green I (Molecular Prober, Eugene, OR) and photographed on a Dark Reader transilluminator (Clare Chemical Research, Dolores, $\mathrm{CO}$ ). PCR product was purified using an UltraClean PCR Clean-Up Kit (Mo Bio Laboratories, Carlsbad, CA). Sequencing was performed bidirectionally with the amplification primers at the University of Minnesota Genomics Center. Sequences were assembled using Sequencher 4.10.1 (Gene Codes Corporation, Ann Arbor, MI) and compared with known sequences in the National Center for Biotechnology Information (NCBI) for identification. Species identification was accomplished by comparing the ITS and Cox 1 sequence data of the unknown isolates against data in the NCBI (www.ncbi.nlm.nih. gov) database using BLAST to compare sequences to published Pythium and Phytopythium spp. data. Most isolates were very closely related (matching or within 1 to 2 bp difference) to isolates submitted and published by Robideau et al. (2011). Queries with $95 \%$ or better coverage and the fewest base pairs difference $(<6 \mathrm{bp})$ were considered a species match.
Seed assay. Forty-three isolates representing the 21 most common Pythium and Phytopythium spp. isolated from these studies were tested for pathogenicity (Table 1). These isolates were chosen if they survived storage at $4{ }^{\circ} \mathrm{C}$ for 1 to 2 years from the date they were isolated to the date they were revitalized for DNA extraction and if their identity was verifiable based on DNA sequences of two gene targets. Up to three isolates of each species were included in the pathogenicity assay. Isolates were grown on CMA for 1 week and then ca. $4 \mathrm{~mm}^{2}$ plugs were transferred to eight petri plates containing $1 \%$ water agar plates. Five surface-sterilized seeds of the soybean cultivar McCall were placed around the perimeter of the plate equidistant from each other within $1 \mathrm{~cm}$ of the plate's edge prior to placement in a dark incubator either at 15,20 , or $25^{\circ} \mathrm{C}$. Nine-day-old roots were scanned on a Epson V600 flatbed scanner (Epson, Long Beach, CA). After removing background debris and optimizing the contrast in Photoshop Elements 9.0 (Adobe, San Jose, CA), the images were analyzed in WinRhizo Basic 2013 (Regent Instruments Inc., Quebec City, Quebec) to determine the average total root length of the seedlings on each plate. Root lengths on inoculated plates were divided by those on uninoculated plates to determine the average root length ratio. The experiment was repeated once at each temperature. Pathogenicity

Table 1. Pythium spp. and isolates from this study evaluated for aggressiveness as seed and seedling pathogens and for sensitivity to fungicides ${ }^{\mathrm{a}}$

\begin{tabular}{|c|c|c|c|c|c|c|c|c|}
\hline Species name & Isolate name & County & Isolation year & Source & Clade & Seed & Seedling & Fungicide \\
\hline \multirow[t]{2}{*}{ Phytopythium boreale } & LSJ 1-4 & Jackson & 2013 & Soil & Phy & $\mathrm{x}$ & $\mathrm{x}$ & \\
\hline & LSJ 3-1 & Jackson & 2013 & Soil & Phy & $\mathrm{x}$ & & \\
\hline Phytopythium litorale & MN7KK & Polk & 2012 & Seedling & Phy & $\mathrm{x}$ & $\mathrm{x}$ & $\mathrm{x}$ \\
\hline \multirow[t]{2}{*}{ Phytopythium megacarpum } & LSM3 1-4 & Martin & 2013 & Soil & Phy & $\mathrm{x}$ & & \\
\hline & LSM1 3-3 1 & Martin & 2013 & Soil & Phy & $\mathrm{x}$ & $\mathrm{x}$ & \\
\hline Pythium acrogynum & MNSO_1-50.1h & Waseca & 2011 & Seedling & E & $\mathrm{x}$ & $\mathrm{x}$ & $\mathrm{x}$ \\
\hline \multirow[t]{3}{*}{ Pythium attrantheridium } & C-MNSO2_4-5 & McLeod & 2012 & Seedling & $\mathrm{F}$ & $\mathrm{x}$ & & \\
\hline & MNSO_2-7.1r & Martin & 2011 & Seedling & $\mathrm{F}$ & $\mathrm{x}$ & & \\
\hline & MNSO_4-2.1r & Wilkin & 2011 & Seedling & $\mathrm{F}$ & $\mathrm{x}$ & $\mathrm{x}$ & \\
\hline Pythium conidiophorum & MNSO_1-28.1r & Waseca & 2011 & Seedling & B & $\mathrm{x}$ & $\mathrm{x}$ & $\mathrm{x}$ \\
\hline \multirow{3}{*}{ Pythium heterothallicum } & C-MNSO2_6-22 & Clay & 2012 & Seedling & I & $\mathrm{x}$ & & \\
\hline & PAKZ 1-4 & McLeod & 2013 & Soil & I & $\mathrm{x}$ & & \\
\hline & MNSO_2-41.1h & Martin & 2011 & Seedling & I & $\mathrm{x}$ & $\mathrm{x}$ & \\
\hline \multirow[t]{2}{*}{ Pythium inflatum } & Kerber $1-3$ & Carver & 2013 & Soil & B & $\mathrm{x}$ & $\mathrm{x}$ & \\
\hline & PAKZ 1-3 1 & McLeod & 2013 & Soil & B & $\mathrm{x}$ & & \\
\hline \multirow[t]{3}{*}{ Pythium intermedium } & C-MNSO2_6-1 & Clay & 2012 & Seedling & $\mathrm{F}$ & $\mathrm{x}$ & $\mathrm{x}$ & $\mathrm{x}$ \\
\hline & C-MNSO2_6-13 & Clay & 2012 & Seedling & $\mathrm{F}$ & $\mathrm{x}$ & & $\mathrm{x}$ \\
\hline & V-MNSO2_6-44 & Clay & 2012 & Seedling & $\mathrm{F}$ & $\mathrm{x}$ & & $\mathrm{x}$ \\
\hline \multirow[t]{3}{*}{ Pythium irregulare } & Kloss 8 & Benton & 2013 & Soil & $\mathrm{F}$ & $\mathrm{x}$ & $\mathrm{x}$ & $\mathrm{x}$ \\
\hline & CCNC 2-2 & Isanti & 2013 & Soil & $\mathrm{F}$ & $\mathrm{x}$ & & $\mathrm{x}$ \\
\hline & RIL173 & Ramsey & NA & Seedling & $\mathrm{F}$ & $\mathrm{x}$ & & $\mathrm{x}$ \\
\hline Pythium minus & MNSO_1-38.2h & Waseca & 2011 & Seedling & E & $\mathrm{x}$ & $\mathrm{x}$ & \\
\hline Pythium nagaii & C-MNSO2_6-21 & Clay & 2012 & Seedling & $\mathrm{G}$ & $\mathrm{x}$ & $\mathrm{x}$ & \\
\hline \multirow[t]{3}{*}{ Pythium oopapillum } & V-MNSO2_1-63 & Waseca & 2012 & Seedling & B & $\mathrm{x}$ & & $\mathrm{x}$ \\
\hline & MNSO_2-20.1h & Martin & 2011 & Seedling & B & $\mathrm{x}$ & $\mathrm{x}$ & $\mathrm{x}$ \\
\hline & MNSO_5-20.1h & Redwood & 2011 & Seedling & B & $\mathrm{x}$ & & $\mathrm{x}$ \\
\hline Pythium perplexum & C-MNSO2_3-15 & Clay & 2012 & Seedling & $\mathrm{J}$ & $\mathrm{x}$ & $\mathrm{x}$ & \\
\hline Pythium pleroticum & Kramer 1-3 & Renville & 2013 & Soil & $\mathrm{E}$ & $\mathrm{x}$ & $\mathrm{x}$ & \\
\hline \multirow[t]{3}{*}{ Pythium recalcitrans } & Kloss 10 & Benton & 2013 & Soil & $\mathrm{F}$ & $\mathrm{x}$ & & $\mathrm{x}$ \\
\hline & C-MNSO2_4-25 & McLeod & 2012 & Seedling & $\mathrm{F}$ & $\mathrm{x}$ & $\mathrm{x}$ & $\mathrm{x}$ \\
\hline & Kerber 8 & Carver & 2013 & Soil & $\mathrm{F}$ & $\mathrm{x}$ & & $\mathrm{x}$ \\
\hline \multirow[t]{2}{*}{ Pythium schmitthenneri } & PAKZ 2-3 & McLeod & 2013 & Soil & $\mathrm{E}$ & $\mathrm{x}$ & & \\
\hline & PAKZ 2-4 & McLeod & 2013 & Soil & $\mathrm{E}$ & $\mathrm{x}$ & $\mathrm{x}$ & \\
\hline \multirow[t]{2}{*}{ Pythium sylvaticum } & MNSO_1-13.1h & Waseca & 2011 & Seedling & $\mathrm{F}$ & $\mathrm{x}$ & & $\mathrm{x}$ \\
\hline & MNSO_3-47.2r & Clay & 2011 & Seedling & $\mathrm{F}$ & $\mathrm{x}$ & $\mathrm{x}$ & $\mathrm{x}$ \\
\hline \multirow[t]{3}{*}{ Pythium torulosum } & Zimmerman 2-3 & McLeod & 2013 & Soil & $\mathrm{B}$ & $\mathrm{x}$ & & \\
\hline & C-MNSO2_2-21 & Renville & 2012 & Seedling & B & $\mathrm{x}$ & $\mathrm{x}$ & \\
\hline & MNSO_2-25.1h & Martin & 2011 & Seedling & $\mathrm{B}$ & $\mathrm{x}$ & & \\
\hline \multirow[t]{2}{*}{ Pythium ultimum var. sporangiiferum } & V-MNSO2_1-59 & Waseca & 2012 & Seedling & I & $\mathrm{x}$ & $\mathrm{x}$ & $\mathrm{x}$ \\
\hline & V-MNSO2_3-58 & Clay & 2012 & Seedling & I & $\mathrm{x}$ & & $\mathrm{x}$ \\
\hline \multirow[t]{3}{*}{ Pythium ultimum var. ultimum } & MNSO_1-20.1h & Waseca & 2011 & Seedling & I & $\mathrm{x}$ & $\mathrm{x}$ & $\mathrm{x}$ \\
\hline & C-MNSO2_5-9 & Redwood & 2012 & Seedling & I & $\mathrm{x}$ & & $\mathrm{x}$ \\
\hline & Clay $1-1$ & Clay & 2013 & Soil & I & $\mathrm{x}$ & & $\mathrm{x}$ \\
\hline
\end{tabular}

$\overline{{ }^{a}}$ Columns indicate isolate designation, originating county, year collected, source from soil or seedlings, clade, and use in this study. NA indicates collection date not recorded. 
was evaluated on corn hybrid 'Viking 60-01 N', using the same methods as those used for soybean except that plates were incubated for 6 days.

Seedling assay. Pathogenicity on soybean and corn seedlings was determined using an assay similar to that described by Zhang and Yang (2000). A single isolate of each of the 21 Pythium spp. (Table 1) that was most aggressive, i.e., resulted in the smallest root length ratio, in the in vitro assay was used. Inoculum was made with subcultures grown for 6 days at $20^{\circ} \mathrm{C}$ on five $100 \mathrm{~mm}$ petri dishes containing CMA. The media from the six plates was forced through a $0.64 \mathrm{~cm}$ wire mesh and thoroughly mixed with 2.5 liters of vermiculite before being evenly distributed among five $10.2 \mathrm{~cm}$ plastic pots. Five seeds of soybean cultivar McCall were planted in each pot. Pots were then placed in flooded plastic trays without drainage holes and placed in the greenhouse with sunlight supplemented by artificial light for a $16 \mathrm{~h}$ photoperiod with temperatures ranging from $28^{\circ} \mathrm{C}$ during the day to $15^{\circ} \mathrm{C}$ at night. Each group of seedlings inoculated with the 21 Pythium spp. was paired with an uninoculated (CMA-only) set of control seedlings in a separate tray which were randomized within each tray. Trays were arranged in a randomized complete block design (RCBD) replicated five times. After 14 days, emerged seedlings were removed from pots, washed, and dried. Root dry weights were measured. Corn seedlings were inoculated in the same manner and maintained in a greenhouse where temperatures ranged from 17 to $33^{\circ} \mathrm{C}$.

Sensitivity of isolates to fungicides. Twenty-two isolates representing 10 pathogenic Pythium spp. (Table 1) were assayed for sensitivity to five commercial fungicides commonly applied as seed treatments using the procedure of Broders et al. (2007). The fungicides were azoxystrobin (Dynasty 100FS; Syngenta Crop Protection, Greensboro, NC), ethaboxam (Intego Solo; Valent, Walnut Creek, CA), mefenoxam (Apron XL; Syngenta Crop Protection, Greensboro, NC), pyraclostrobin (Stamina; BASF, Research Triangle, NC), and trifloxystrobin (Trilex FS; Research Triangle, NC). A $4 \mathrm{~mm} \times 4 \mathrm{~mm}$ block from a 1-week-old culture of each Pythium isolate grown on CMA was placed at the center of a plate containing either CMA amended with a fungicide as formulated product or unamended CMA. The fungicide was first dissolved in approximately 1 to $2 \mathrm{ml}$ of water to better facilitate its mixing with the media. The sensitivity of the 22 isolates was tested at three concentrations for each fungicide including a concentration determined in preliminary experiments to be the concentration at which Pythium growth was inhibited approximately $50 \%$ by the respective fungicide. Sensitivity of each isolate was also assayed to all fungicides at the same two concentrations: 100 and $5 \mu \mathrm{g}$ a.i./ml. Fungicide concentrations at which Pythium growth was inhibited approximately $50 \%$ by the respective fungicide, azoxyxtrobin, ethaboxam, mefenoxam, pyraclostrobin, or trifloxystrobin, were, $0.5,0.1,1$, or $250 \mu \mathrm{g}$ a.i./ml, respectively. Plates were placed in an $18^{\circ} \mathrm{C}$ incubator for $48 \mathrm{~h}$ and then the average colony diameter was determined by measuring each colony twice at right angles centered on the midpoint of the inoculating block of CMA.

The effect of the fungicide was calculated as the ratio of the treated versus untreated colony diameter and the relative growth reduction was calculated as $1-$ (ratio of the treated versus untreated colony diameters). Three plates of each fungicide were used for each experiment and the experiment was conducted three times. Plates were considered technical replicates within days and averaged to get a single estimate for each isolate/treatment (amended with fungicide or not amended) combination for each day. Then, as the estimate of interest was the percentage comparing the colony diameter resulting from the fungicide amendment to the colony diameter of the control (unamended) value, these percentages were calculated for each isolate/fungicide treatment combination for each day by dividing the fungicide amended value by unamended value. For each isolate/ treatment combination there is then one data point for each experimental unit (day), allowing the use of nonlinear least squares, which assumes independence of the data points. To find the $\mathrm{EC}_{50}$ value for each isolate/treatment combination, a piecewise exponential curve was then fitted with knots at the amended concentration values. For each piece, this curve was written as $y=\exp (-k \times x+b)$, where $y$ is the percent and $x$ is the concentration. For the first piece, $b$ was set to zero, as the percent at concentration zero (the control) is $100 \%$. Each piece was then parameterized instead as $y=\exp (-(\log (2)+b) \times x / \exp$ $\left(\log \mathrm{EC}_{50}\right)+b$ ) to directly estimate the $\log$ of the $\mathrm{EC}_{50}$ value. The $\log$ scale was chosen because the sampling distribution of the parameter is then more normally distributed, allowing for confidence intervals to be computed directly from estimates of the standard error. The fitted values for each piece of the curve can be found analytically, but to find the confidence intervals, the nonlinear least squares function in $\mathrm{R}$ version 3.2.0 (R Core Team 2016) was used to obtain the standard error. Confidence intervals were calculated on the log concentration scale and then back-transformed to the original scale. Only the piece of the line that crossed the $50 \%$ line was used to find the standard errors; this did occasionally result in large standard errors as the data at the concentrations above and below $50 \%$ were both near $50 \%$.

Statistical analysis. Data from replicated experiments conducted to determine pathogenicity on both seed and seedling were tested for normality and homogeneity of variance. The data required transformation for stabilization of variance and to normalize the distribution.

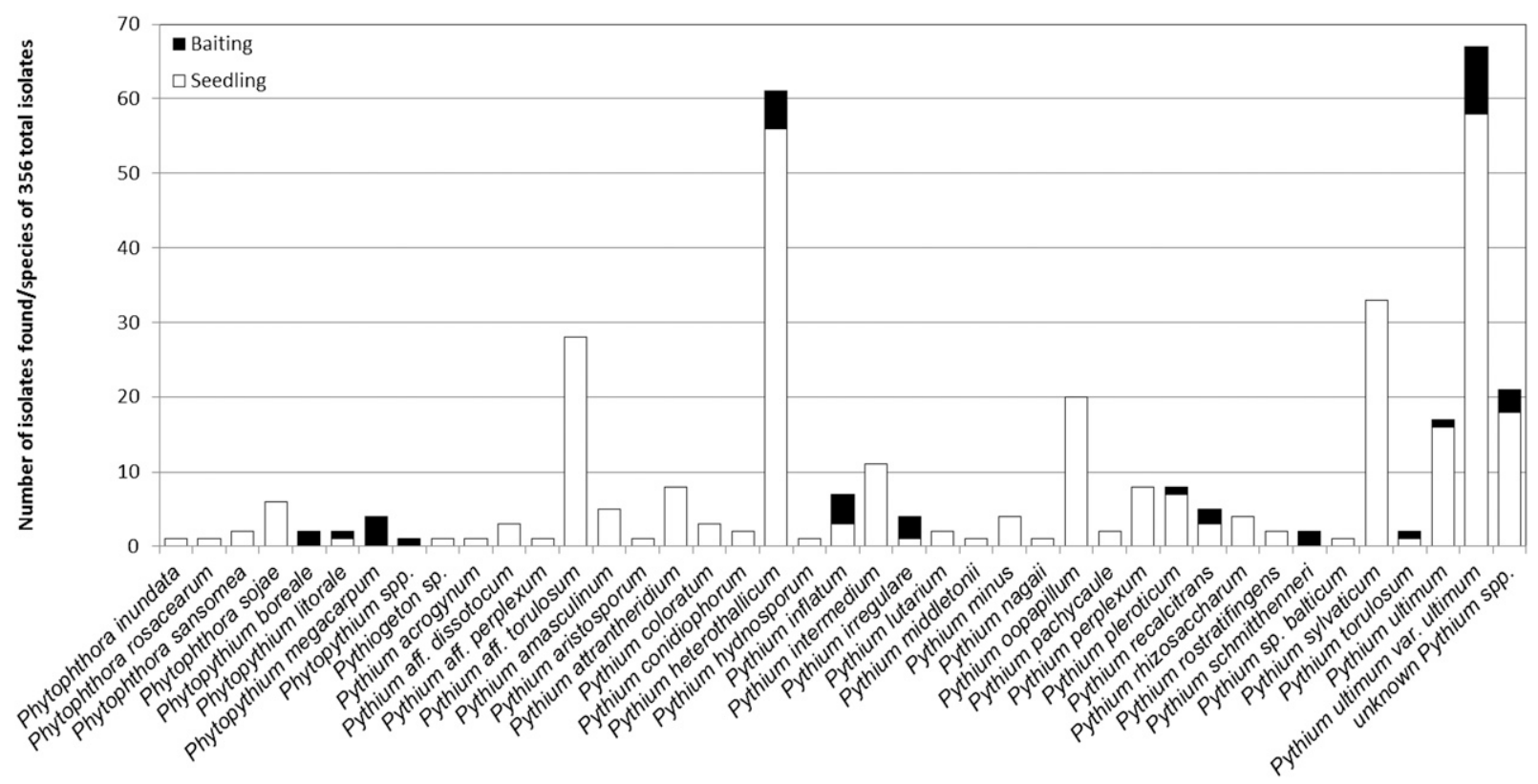

Fig. 2. Identities and frequencies of Phytophthora, Phytopythium, Pythiogeton, and Pythium spp. isolated from seedling and soil samples collected in soybean fields. 
Box-Cox analysis indicated that a log transformation was adequate for transformation. The transformed data were analyzed with PROC GLM (SAS Institute, Cary, NC), and mean separation conducted comparing all means in the experiment using Fisher's least significant difference test, $P \leq 0.05$ or, if the results of inoculation were compared with an untreated control, mean separation was performed using Dunnett's test of significance at $P \leq 0.05$. The treatment values were then back-transformed for graphical and tabular presentation.

\section{Results}

Isolation and identification of Pythium isolates. Pythium isolates were recovered from either soil or soybean seedling samples collected from 49 soybean fields in Minnesota (Fig. 1). Baiting of soil samples collected from 37 fields in 15 counties in 2011 to 2013 yielded 31 Pythium and eight Phytopythium isolates. Isolation from seedling samples collected in 12 fields in eight counties in 2011 and 2012 yielded 305 Pythium and one Phytopythium isolate. Among the isolates obtained from both plant and soil samples were 31 known and affinis Pythium spp., and three Phytopythium spp. Also recovered were 21 unknown Pythium isolates, one unknown Phytopythium, and one unknown Pythiogeton isolate (Fig. 2). P. ultimum var. ultimum was the species found most frequently with 67 isolates recovered (Fig. 2). $P$. heterothallicum and $P$. sylvaticum were the second and third most frequently occurring species with 61 and 33 isolates, respectively. Five isolates of the newly described species, $P$. recalcitrans, were found. Forty-four isolates, from 21 different Pythium and Phytopythium spp. were chosen for further analysis of pathogenicity and fungicide sensitivity (Table 1).

Seed assay. The emerging radical from inoculated seeds exhibited visible symptoms including stunting and water soaked lesions. Species were declared pathogenic when the ratio of root length of inoculated seedlings was decreased by $20 \%$ or more compared with the root length of uninoculated seedlings. Aggressiveness of isolates differed significantly among species and was influenced by temperature. Of the 21 species tested (Table 1), seven Pythium spp. were pathogenic on both soybean and corn: $P$. conidiophorum, $P$. intermedium, $P$. irregulare, $P$. recalcitrans, $P$. sylvaticum, $P$. ultimum var. sporangiiferum, and P. ultimum var. ultimum (Fig. 3). Two additional
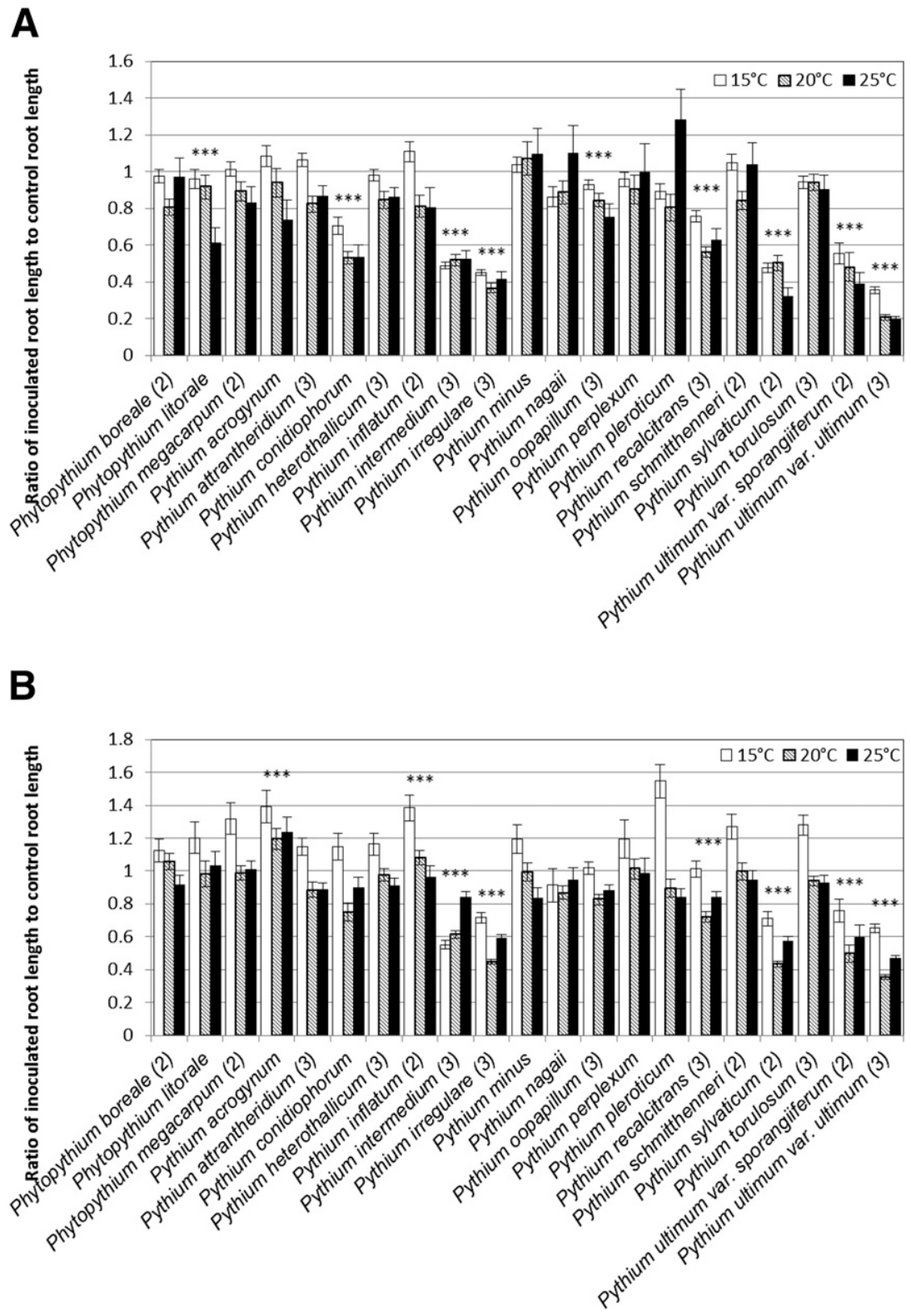

Fig. 3. Aggressiveness of Pythium or Phytopythium spp. to A, soybean or B, corn seedlings indicated by root length ratios of inoculated compared with uninoculated control seedlings at three different temperatures: 15,20 , or $25^{\circ} \mathrm{C}$. Numbers in parenthesis represent the number of isolates that were tested. Columns noted with ${ }^{* * *}$ heading indicate comparisons significant at the 0.05 level between treated and untreated roots according to Dunnett's $t$ tests. Error bars indicate standard error among three temperatures for the individual isolate. 
Pythium species, P. acrogynum, P. oopapillum, and one Phytopythium species, Phytopythium litorale, were pathogenic on soybean but not on corn (Fig. 3A). Pythium ultimum var. ultimum caused the most severe root length reduction, up to $80 \%$ in soybean and $65 \%$ in corn (Fig. 3). Pythium sylvaticum and $P$. irregulare were the second most aggressive Pythium spp. infecting soybean while $P$. irregulare was the second most aggressive Pythium spp. infecting corn causing average reductions in root length greater than 50\% and 55\%, respectively (Fig. 3). In soybean, in all cases but $P$. acgrogynum, which reduced root length ratio below $80 \%$ only at $25^{\circ} \mathrm{C}$, this difference of $20 \%$ or greater was significantly different from the controls averaged across all temperatures tested. Averaged over all Pythium isolates and species the effect of infection of corn appeared to be less severe than infection of soybean.

The response to temperature of the Pythium isolates recovered in our survey differed among species. An increase in temperature was associated with an increase in aggressiveness for 16 of the 21 Pythium and Phytopythium spp. evaluated on soybean and for 19 of 21 species evaluated on corn (Fig. 3). In soybean inoculated with Phytopythium litorale a temperature increase from 15 to $25^{\circ} \mathrm{C}$ resulted in a $35 \%$ reduction in the ratio of inoculated to uninoculated root lengths (Fig. $3 \mathrm{~A})$. In corn, the most extreme responses to changes in temperature occurred with infection by $P$. irregulare, which reduced root growth by $30 \%$ when temperature was increased from 15 to $20^{\circ} \mathrm{C}$ (Fig. 3B).

Infection by Pythium spp. did not always result in reduced root growth of corn or soybean. In some cases, an increase in total root length was observed in the inoculated seedlings when compared with the uninoculated control, resulting in an inoculated to uninoculated ratio greater than one. The most dramatic example, 1.54, occurred when corn was inoculated with $P$. pleroticum and maintained at $15^{\circ} \mathrm{C}$ (Fig. 3B). A $28 \%$ increase in root mass was also observed when soybean was inoculated with $P$. pleroticum and maintained at $25^{\circ} \mathrm{C}$ (Fig. 3A). A similar but less pronounced increase in root mass occurred in corn inoculated with $P$. acrogynum and $P$. inflatum.

Seedling assay. Soybean seedlings grown for two weeks in soil infested with Pythium spp. in the greenhouse displayed a range of responses to inoculation with Pythium spp. (Fig. 4). The severity of visible symptoms varied considerably among inoculated plants and did not appear to be correlated with the effect of inoculation on seedling growth. Inoculated seedlings had reduced root development accompanied by stunting and sometimes wilting and damping-off. Lesions and sometimes water soaking were present on the hypocotyls and cotyledons of the most severely affected seedlings. Two Pythium spp., $P$. irregulare and $P$. ultimum var. sporangiiferum, decreased root mass by more than $10 \%$ when compared with the noninfested controls (Fig. 4A). In contrast, P. minus, P. pleroticum, and P. ultimum var. ultimum increased root length more than $10 \%$. In corn, inoculation with $P$. oopapillum, $P$. irregulare, and $P$. ultimum var. sporangiiferum caused the greatest decrease in root mass (Fig. 4B). Inoculation with $P$. attrantheridium, $P$. recalcitrans, and $P$. schmitthenneri resulted in the greatest increase.

Sensitivity of isolates to fungicides. Sensitivity to the fungicides azoxystrobin, ethaboxam, mefenoxam, pyraclostrobin, or trifloxystrobin, was tested on 22 isolates from 10 pathogenic species with fungicide amended media (Table 1). All isolates were sensitive to the five fungicides tested and exhibited some reduction in growth when exposed to the lowest concentration of the fungicide (data not shown); however, much greater concentrations of the strobilurin fungicides azoxystrobin and trifloxystrobin were necessary to reduce growth of any isolate than the concentration of either ethaboxam or mefenoxam. In some instances, there was a greater than $80 \%$ difference in fungicide sensitivity between species within the same fungicide treatment (Fig. 5).

The strobilurins were less effective as fungicides against the Pythium spp. isolated in this survey. Of the strobilurins, azoxystrobin (Fig. 5A; Table 2) was effective against more of the Pythium spp. tested than trifloxystrobin (Table 2). It was most effective against P. oopapillum, with $\mathrm{EC}_{50}$ values near $4 \mu \mathrm{g}$ a.i. $\mathrm{ml}^{-1}$ (Table 2 ) but was less effective than pyraclostrobin against $P$. irregulare (Table 2). Pyraclostrobin had the greatest effect against $P$. recalcitrans, $P$. oopapillum, and $P$. intermedium. $P$. conidiophorum and $P$. irregulare were much more tolerant of this fungicide at concentrations lower than $100 \mu \mathrm{g}$ a.i. $\mathrm{ml}^{-1}$ (Fig. 5D). Trifloxystrobin was not an effective fungicide against the Pythium species tested with the exception of P. oopapillum which displayed some sensitivity to it (Fig. 5E, Table 2).

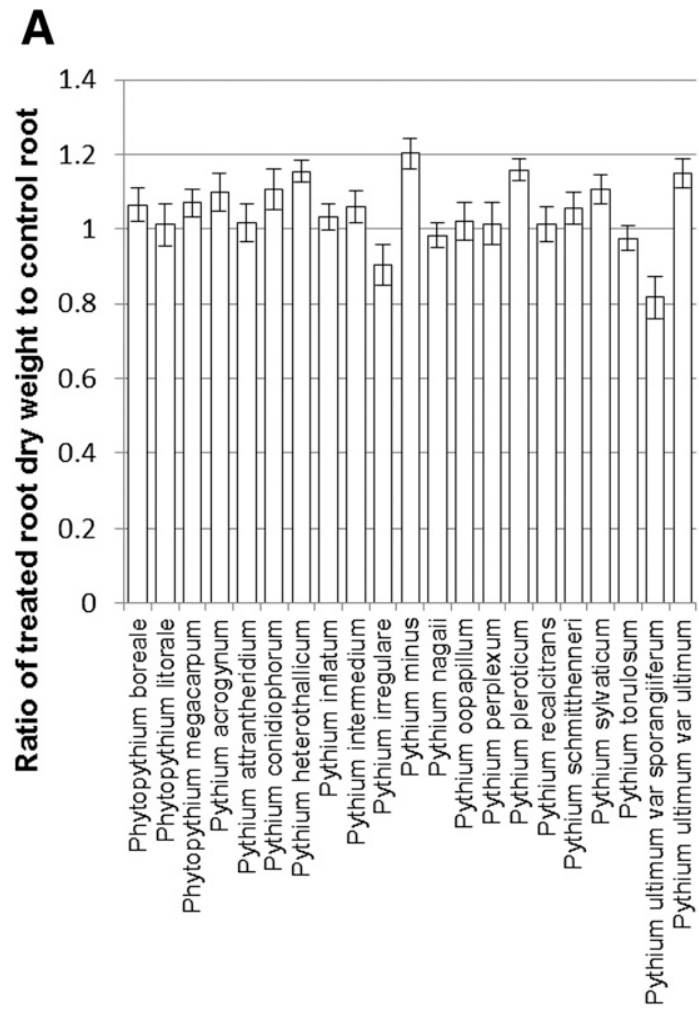

B

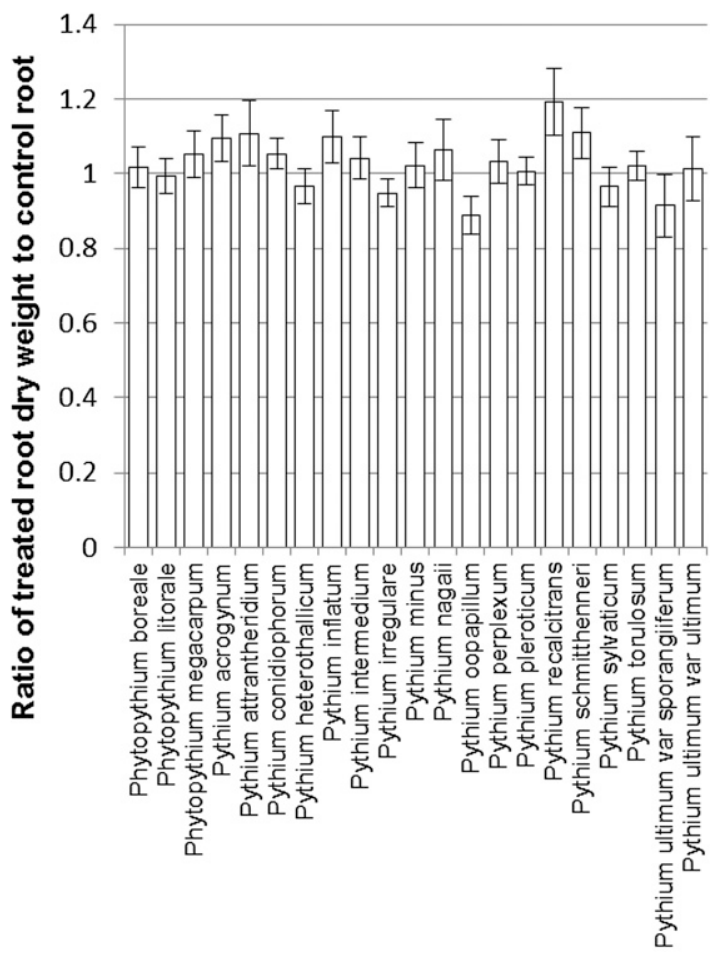

Fig. 4. Aggressiveness of 21 Pythium or Phytopythium spp. on A, soybean or B, corn seedlings. The data show the ratio of the root length of the inoculated seedling divided by the root length of the uninoculated control. Error bars indicate standard error. 
The most effective fungicides tested were the thiazole carboxamide, ethaboxam, and the phenylamide, mefenoxam. Mefenoxam was most effective at reducing or inhibiting growth of all Pythium isolates except for $P$. conidiophorum which exhibited significant growth at 0.1 and $5.0 \mu \mathrm{g}$ a.i. $\mathrm{ml}^{-1}$ (Table 2; Fig. 5C). Ethaboxam was very effective against $P$. intermedium, $P$. oopapillum, and $P$. sylvaticum, with $\mathrm{EC}_{50}$ values below $0.3 \mu \mathrm{g}$ a.i. $\mathrm{ml}^{-1}$ (Table 2). However, $P$. acrogynum and $P$. recalcitrans were insensitive to it at concentrations of 0.5 and $5.0 \mu \mathrm{g}$ a.i. $\mathrm{ml}^{-1}$ (Fig. 5B; Table 2). One isolate of $P$. recalcitrans showed almost no sensitivity to ethaboxam (Table 2). Mefenoxam was the most effective fungicide tested as it had an $\mathrm{EC}_{50}$ below $0.15 \mu \mathrm{g}$ a.i. $\mathrm{ml}^{-1}$ for all but five oomycete isolates tested (Fig. 5B; Table 2). One notable exception was $P$. conidiophorum which displayed very little sensitivity at low concentrations (Fig. 5C).

While there was some variation in sensitivity to particular fungicides among individual isolates within a species, in most cases there was no significant difference in reaction among the multiple isolates within a species (data not shown). However, this was not true of all Pythium spp. tested; $P$. recalcitrans shows considerable variation between isolates when exposed to azoxystrobin, ethaboxam, and pyraclostrobin (Fig. 6A). There were significant differences in sensitivity between the two isolates of $P$. ultimum var. sporangiiferum when tested with ethaboxam, mefenoxam, and trifloxystrobin (Fig. 6B).

\section{Discussion}

This study highlights the diversity of Pythium spp. associated with soybean in Minnesota and their varied pathogenicity traits, environmental responses, and sensitivities to fungicides. Overall, 30 Pythium spp. and four Phytopythium spp., a new genus combining features of Pythium and Phytophthora spp. (de Cock et al. 2015) were found in Minnesota soybean fields. This is a much greater number of Pythium spp. than was reported in the last study conducted in Minnesota (Brown and Kennedy 1965) when only three pathogenic species were found. This study identified nine pathogenic Pythium and one pathogenic Phytopythium spp. Phytopythium is a new genus described by Bala et al. (2010) with Phytopythium sindhum as the type species. The genus is made up of species formerly assigned to Pythium species clade K but reassigned to Phytopythium on the basis of phylogenic analyses performed by de Cock et al. (2015). Neither the presence of Phytopythium spp. nor the pathogenicity of
A

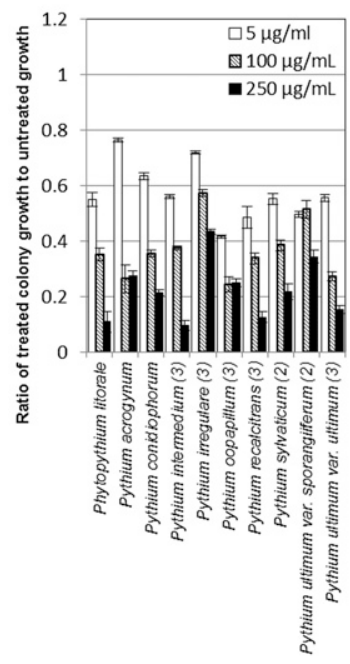

D

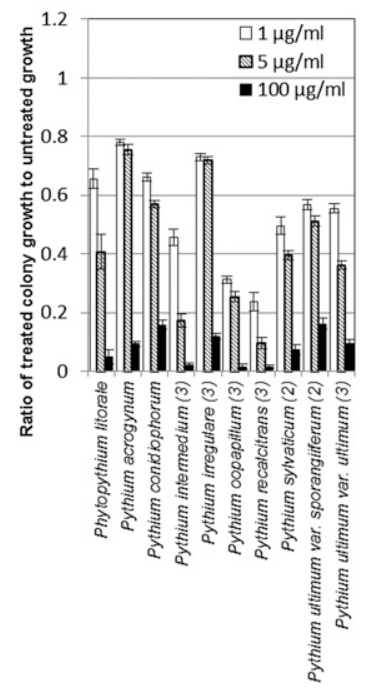

B

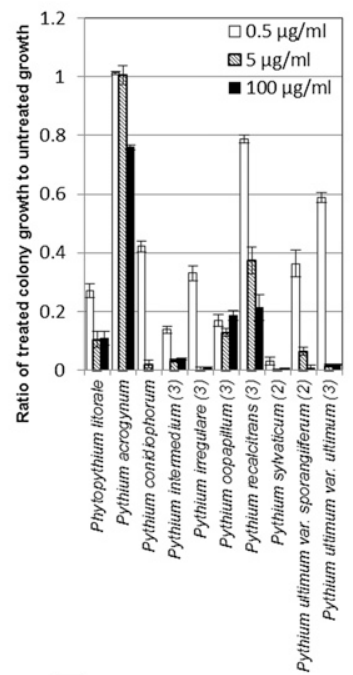

$\mathbf{E}$

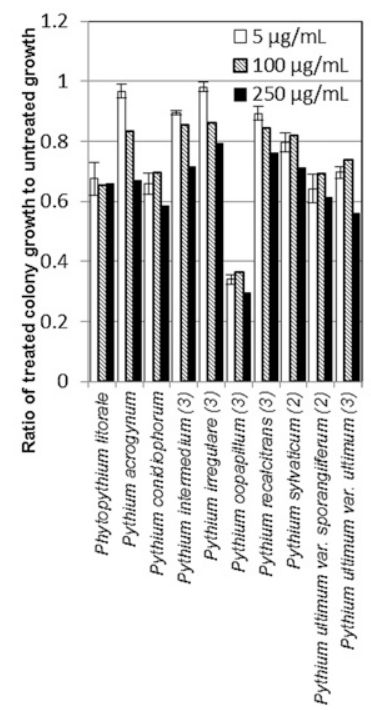

Fig. 5. Growth of Pythium and Phytopythium spp. on potato dextrose agar amended at three concentrations with either A, azoxystrobin, B, ethaboxam, C, mefenoxam, D, pyryclastrobin, or $\mathbf{E}$, trifloxystrobin. Mycelial growth on fungicide treated plates at each concentration is divided by the mycelial growth on the unamended control media to determine effect of fungicide addition on aggressiveness of the fungus. Numbers in parentheses represent multiple isolates tested. Error bars indicate standard error among three concentrations for the individual isolate and treatment. 
Phytopythium litorale on soybean had been reported previously in Minnesota. Similar recent studies conducted in other states where soybean was grown in rotation with corn have also yielded high levels of diversity but the Pythium spp. found in those studies differed greatly among the states (Broders et al. 2007; Jiang et al. 2012; Marchand et al. 2014; Zitnick-Anderson and Nelson 2014). For example, we and Zitnick-Anderson and Nelson (2014) isolated $P$. aristosporum, $P$. attrantheridium, $P$. coloratum, $P$. dissotocum, $P$. heterothallicum, $P$. intermedium, $P$. irregulare, $P$. lutarium, $P$. minus, $P$. oopapillum, $P$. perplexum, $P$. sylvaticum, and $P$. ultimum from soybean seedlings. Zitnick-Anderson and Nelson (2014) isolated 10 additional Pythium spp. not found in our study including $P$. arrhenomanes, $P$. debaryanum, $P$. diclinum, $P$. hypogynum, $P$. inflatum, $P$. kashmirense, $P$. nunn, $P$. orthogonon, $P$. perilum, $P$. rostratifingens, $P$. terrestris, $P$. viniferum, and $P$. viola. In contrast, in Minnesota we isolated an additional sixteen Pythium spp. and four Phytopythium spp. not isolated in the North Dakota study.

Of the 21 Pythium spp. included in pathogenicity studies seven were pathogenic on both soybean and corn, while two Pythium and one Phytopythium spp. were mildly virulent on soybean at high temperatures but not pathogenic on corn at any temperature. The Pythium isolates were generally also more aggressive on soybean than on corn, which is possibly the result of sampling and isolation methods. Because these two crops are often planted in rotation in Minnesota the ability to infect both crops is a concern because the soilborne inoculum population of Pythium spp. will likely increase when either crop is grown (Martin and Loper 1999). Zhang et al. (1998) studied the diversity of Pythium spp. present under three

Table 2. $\mathrm{EC}_{50}$ values of Phytopythium and Pythium spp. in response to seed treatment fungicides ethaboxam, mefenoxam, azoystrobin, pyraclostrobin, and trifloxystrobin measured in $\mu \mathrm{g} \mathrm{ml}^{-1 \mathrm{a}}$

\begin{tabular}{|c|c|c|c|c|c|c|c|c|c|c|}
\hline \multirow[b]{2}{*}{ Species } & \multirow[b]{2}{*}{ Isolate } & \multicolumn{3}{|c|}{ Ethaboxam } & \multicolumn{3}{|c|}{ Mefenoxam } & & & \\
\hline & & $\mathbf{E C}_{50}$ & CI lower & CI upper & $\mathbf{E C}_{50}$ & CI lower & CI upper & & & \\
\hline Phytopythium litorale & MN7KK & 0.266 & 0.165 & 0.429 & 0.104 & 0.003 & 3.791 & & & \\
\hline Pythium acrogynum & $1-50.1 \mathrm{~h}$ & $>100$ & NA & NA & 0.043 & 0.030 & 0.060 & & & \\
\hline Pythium conidiophorum & $1-28.1 \mathrm{r}$ & 0.402 & 0.274 & 0.589 & 4.002 & 2.619 & 6.115 & & & \\
\hline Pythium intermedium & C6-1 & 0.182 & 0.142 & 0.233 & 0.084 & 0.064 & 0.109 & & & \\
\hline Pythium intermedium & C6-13 & 0.208 & 0.124 & 0.350 & 0.086 & 0.080 & 0.094 & & & \\
\hline Pythium intermedium & V6-44 & 0.136 & 0.119 & 0.155 & 0.133 & 0.017 & 1.018 & & & \\
\hline Pythium irregulare & Kloss 8 & 0.197 & 0.147 & 0.264 & 0.073 & 0.051 & 0.106 & & & \\
\hline Pythium irregulare & CCNC $2-2$ & 0.344 & 0.322 & 0.368 & 0.280 & 0.133 & 0.592 & & & \\
\hline Pythium irregulare & RIL173 & 0.438 & 0.206 & 0.933 & 0.076 & 0.040 & 0.143 & & & \\
\hline Pythium oopapillum & V1-63 & 0.142 & 0.089 & 0.227 & 0.084 & 0.066 & 0.107 & & & \\
\hline Pythium oopapillum & $2-20.1 \mathrm{~h}$ & 0.274 & 0.242 & 0.310 & 1.611 & 1.359 & 1.911 & & & \\
\hline Pythium oopapillum & $5-20.1 \mathrm{~h}$ & 0.175 & 0.141 & 0.218 & 0.091 & 0.071 & 0.116 & & & \\
\hline Pythium recalcitrans & Kloss 10 & $>100$ & NA & NA & 0.492 & 0.128 & 1.889 & & & \\
\hline Pythium recalcitrans & $\mathrm{C} 4-25$ & 2.006 & 1.842 & 2.186 & 0.072 & 0.060 & 0.087 & & & \\
\hline Pythium recalcitrans & Kerber 8 & 2.016 & 1.833 & 2.216 & 0.086 & 0.061 & 0.120 & & & \\
\hline Pythium sylvaticum & $1-13.1 \mathrm{~h}$ & 0.080 & 0.064 & 0.100 & 0.057 & 0.026 & 0.126 & & & \\
\hline Pythium sylvaticum & $3-47.2 \mathrm{r}$ & 0.108 & 0.051 & 0.231 & 0.044 & 0.024 & 0.081 & & & \\
\hline Pythium ultimum var. sporangiiferum & V1-59 & 0.622 & 0.423 & 0.916 & 0.036 & 0.033 & 0.039 & & & \\
\hline Pythium ultimum var. sporangiiferum & V3-58 & 0.198 & 0.174 & 0.226 & 1.132 & 0.682 & 1.880 & & & \\
\hline Pythium ultimum var. ultimum & $1-20.1 \mathrm{~h}$ & 0.775 & 0.615 & 0.978 & 0.030 & 0.020 & 0.044 & & & \\
\hline Pythium ultimum var. ultimum & C5-9 & 0.662 & 0.367 & 1.195 & 0.026 & 0.014 & 0.051 & & & \\
\hline \multirow[t]{2}{*}{ Pythium ultimum var. ultimum } & Clay 1-1 & 0.655 & 0.523 & 0.820 & 0.020 & 0.011 & 0.038 & & & \\
\hline & & \multicolumn{3}{|c|}{ Azoystrobin } & \multicolumn{3}{|c|}{ Pyraclostrobin } & \multicolumn{3}{|c|}{ Trifloxystrobin } \\
\hline Species & Isolate & $\mathbf{E C}_{50}$ & CI lower & CI upper & $\mathbf{E C}_{50}$ & CI lower & CI upper & $\mathbf{E C}_{50}$ & CI lower & CI upper \\
\hline Phytopythium litorale & MN7KK & 25.305 & 5.525 & 115.897 & 3.284 & 1.266 & 8.518 & $>250$ & NA & NA \\
\hline Pythium acrogynum & $1-50.1 \mathrm{~h}$ & 43.050 & 22.871 & 81.035 & 23.667 & 17.447 & 32.106 & $>250$ & NA & NA \\
\hline Pythium conidiophorum & $1-28.1 \mathrm{r}$ & 43.786 & 38.712 & 49.524 & 14.624 & 8.514 & 25.119 & $>250$ & NA & NA \\
\hline Pythium intermedium & C6-1 & 29.373 & 14.249 & 60.549 & 0.884 & 0.522 & 1.496 & $>250$ & NA & NA \\
\hline Pythium intermedium & C6-13 & 31.515 & 22.240 & 44.658 & 0.737 & 0.142 & 3.832 & $>250$ & NA & NA \\
\hline Pythium intermedium & V6-44 & 32.949 & 15.256 & 71.161 & 1.189 & 0.620 & 2.280 & $>250$ & NA & NA \\
\hline Pythium irregulare & Kloss 8 & 204.411 & 162.035 & 257.870 & 24.231 & 16.319 & 35.979 & $>250$ & NA & NA \\
\hline Pythium irregulare & $\mathrm{CCNC} 2-2$ & 171.433 & 135.391 & 217.068 & 29.149 & 21.231 & 40.021 & $>250$ & NA & NA \\
\hline Pythium irregulare & RIL173 & 132.848 & 57.875 & 304.943 & 19.397 & 10.998 & 34.208 & $>250$ & NA & NA \\
\hline Pythium oopapillum & V1-63 & 4.166 & 3.512 & 4.942 & 0.697 & 0.523 & 0.928 & 3.899 & 3.340 & 4.551 \\
\hline Pythium oopapillum & $2-20.1 \mathrm{~h}$ & 3.699 & 3.284 & 4.168 & 0.560 & 0.346 & 0.909 & 3.119 & 2.764 & 3.520 \\
\hline Pythium oopapillum & $5-20.1 \mathrm{~h}$ & 4.005 & 3.328 & 4.820 & 0.540 & 0.492 & 0.592 & 2.715 & 1.083 & 6.808 \\
\hline Pythium recalcitrans & Kloss 10 & 2.380 & 1.821 & 3.113 & 0.208 & 0.163 & 0.267 & $>250$ & NA & NA \\
\hline Pythium recalcitrans & $\mathrm{C} 4-25$ & 16.382 & 4.648 & 57.741 & 0.528 & 0.499 & 0.559 & $>250$ & NA & NA \\
\hline Pythium recalcitrans & Kerber 8 & 75.950 & 55.785 & 103.404 & 0.759 & 0.481 & 1.197 & $>250$ & NA & NA \\
\hline Pythium sylvaticum & $1-13.1 \mathrm{~h}$ & 59.529 & 41.903 & 84.569 & 3.080 & 1.246 & 7.614 & $>250$ & NA & NA \\
\hline Pythium sylvaticum & $3-47.2 \mathrm{r}$ & 6.452 & 0.001 & & 0.820 & 0.661 & 1.017 & $>250$ & NA & NA \\
\hline Pythium ultimum var. sporangiiferum & V1-59 & 44.940 & 30.375 & 66.487 & 14.532 & 8.406 & 25.122 & $>250$ & NA & NA \\
\hline Pythium ultimum var. sporangiiferum & V3-58 & 188.827 & 140.987 & 252.899 & 0.993 & 0.909 & 1.084 & $>250$ & NA & NA \\
\hline Pythium ultimum var. ultimum & $1-20.1 \mathrm{~h}$ & 4.890 & 2.986 & 8.007 & 2.440 & 1.622 & 3.668 & $>250$ & NA & NA \\
\hline Pythium ultimum var. ultimum & C5-9 & 4.014 & 2.478 & 6.504 & 1.180 & 0.232 & 5.992 & $>250$ & NA & NA \\
\hline Pythium ultimum var. ultimum & Clay 1-1 & 5.000 & 4.557 & 5.486 & 2.068 & 0.845 & 5.065 & $>250$ & NA & NA \\
\hline
\end{tabular}

${ }^{a}$ Upper and lower limits of the confidence intervals (CI) were computed from estimates of the standard error. 
different crop sequences: continuous corn, a corn-soybean rotation, and continuous soybean. The authors found a greater proliferation of Pythium spp. in the corn-soybean rotation and continuous soybean fields than in the continuous corn fields. They suggested that the use of soybean in a rotation may increase virulent Pythium isolates.

Pythium spp. have different optimal temperatures for infecting soybean (Thomson et al. 1971). In this study the range of temperatures chosen for the seed assay was meant to simulate soil temperatures in Minnesota in spring. Of Pythium spp. tested in our seed pathogenicity assay, most were more aggressive at higher than lower temperatures on both soybean and corn. A possible explanation is that there was no competition from other organisms in the seed assay. Pythium spp. may be tolerant of conditions other organisms find unfavorable, favoring their growth in cool soils with a high moisture content and poor gas exchange (Hendrix and Campbell 1973). Without competition from other microorganisms, Pythium spp. could also proliferate freely in warmer temperatures. Hardman and Dick (1987) isolated Pythium during two consecutive springs to study population densities. They reported that $50 \%$ of the variation in the number of Pythium isolates collected was attributable to temperature such that higher temperatures resulted in higher recoveries of Pythium.

Not all Pythium spp. isolated were pathogenic on soybean or corn. For instance, $P$. heterothallicum, the second most commonly isolated species, had a limited effect on both soybean and corn roots under the experimental conditions applied in this study while $P$. acrogynum was pathogenic on soybean only at $25^{\circ} \mathrm{C}$ and inoculation of corn in the seed assay resulted in an increase in root length when compared with the uninoculated controls.

Several of the Pythium spp. isolated appeared to have a beneficial effect on growth of inoculated soybean and corn, increasing, rather than decreasing, root growth and above-ground biomass. This positive growth response was observed in soybean inoculated with $P$. pleroticum and corn inoculated with $P$. acrogynum and

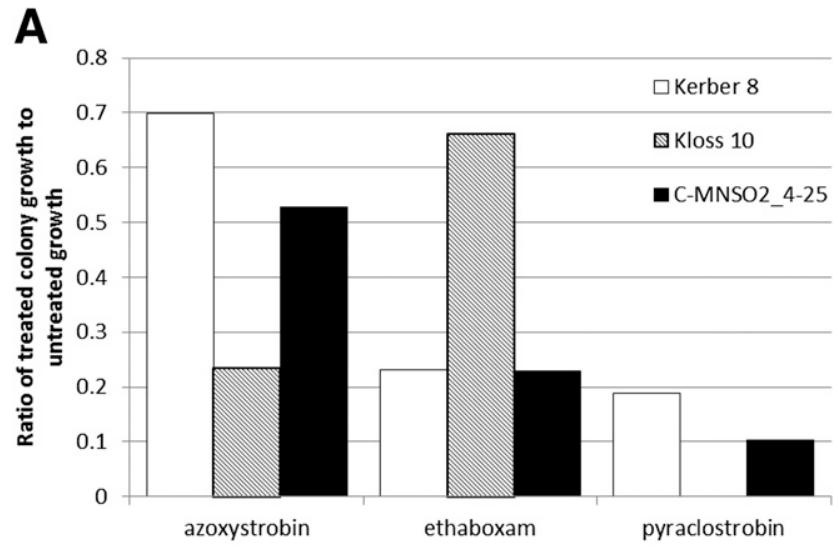

B

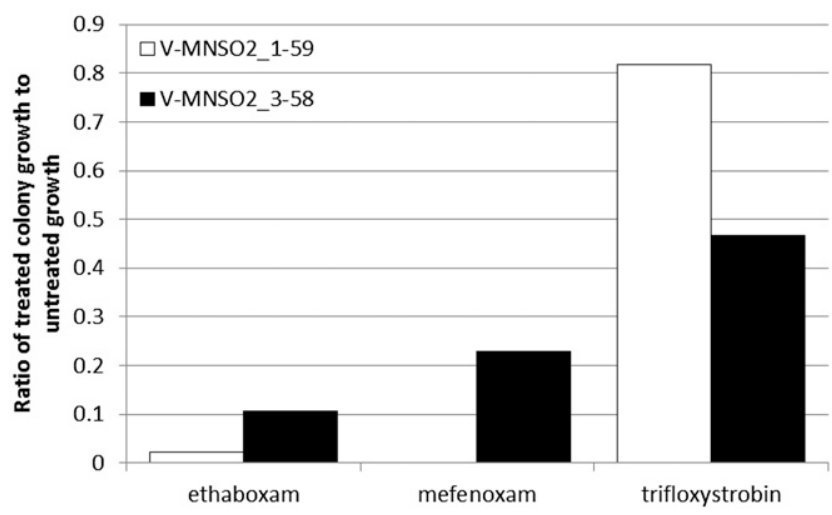

Fig. 6. Intraspecific variation in $\mathbf{A}$, three isolates of Pythium recalcitrans and $\mathbf{B}$, two isolates of $P$. ultimum var. sporangiiferum on media amended with fungicides at a concentration of $5 \mu \mathrm{g} \mathrm{ml}^{-1}$.
$P$. inflatum. The isolates may stimulate plant growth and root proliferation by production of growth stimulating compounds, auxin, cytokinins or gibberellic acid, or by contributing to nutrient mobilization (Blok 1973; Pegg and Selman 1959).

Changes in comparative root mass in the seedling assay did not always correspond with comparative changes in root length and aggressiveness observed in the seed assay. Inoculation with $P$. ultimum var. sporangiiferum and $P$. irregulare resulted in decreased root growth in the seed assay and in decreased root weights in soybean when compared with uninoculated controls but other species pathogenic in the seed assay did not decrease root mass in the seedling assay. In corn, $P$. oopapillum, and to a lesser extent, $P$. ultimum var. sporangiiferum were pathogenic in both assays but other pathogenic species did not did not exhibit the same effect. This may be due, in part, to the inoculum densities present in both assays. It is probable that there are fewer propagative units present per unit volume in the seedling assay than the seed assay, leading to fewer signs of pathogenicity and possibly hormetic effects at low inoculum concentrations (Mattson 2008). For example, inoculation of corn with $P$. recalcitrans resulted in significantly decreased root length in the seed assay but increased root mass in the seedling assay.

This is a first report of $P$. recalcitrans on soybean in Minnesota and a first report of $P$. recalcitrans as a pathogen of soybean and corn. $P$. recalcitrans is a newly described species that was first collected from grape vine roots (Vitis vinifera) in South Africa and common beet (Beta vulgaris) in Spain (Moralejo et al. 2008). It has since been reported to be pathogenic on several other crop plants including carrot (Daucus carota) and sugar beet (Beta vulgaris) (Lu et al. 2013; Nechwatal et al. 2012). In 2012 and 2013 it was found on soybean in Wisconsin, but its pathogenicity on soybean was not determined (Wisconsin Department of Agriculture 2013). The seed assay conducted with the $P$. recalcitrans isolates from Minnesota determined that it is pathogenic to both soybean and corn.

The five fungicides tested varied widely in their efficacy against Pythium and Phytopythium spp. Two of the strobilurin fungicides, azoxystrobin and trifloxystrobin, were not effective against either Pythium or Phytopythium spp. at the rates tested in this study. Increasing trifloxystrobin to $250 \mu \mathrm{g} \mathrm{ml}^{-1}$ did not result in inhibition greater than $50 \%$ for the species tested with the exception of $P$. oopapillum. This may be due, in part, to alternative oxidase respiratory pathways that allow oomycetes to continue to produce ATP in the presence of the fungicides (Broders et al. 2007; Wood and Holloman 2003). Some studies have attempted to ameliorate this by introducing salicylhydroxamic acid (SHAM) in their media. It was decided, in this study, to forgo the SHAM amendment in order to evaluate the relative effectiveness of the compounds as they would be utilized in seed treatment. Initial fungicide concentrations were chosen to maximize the range of interspecific variation.

Of the fungicides tested, mefenoxam was the most effective against the Pythium isolates followed by ethaboxam. Metalaxyl, whose active isomer is mefenoxam, has been used in the United States and in Minnesota as a seed treatment fungicide on corn for decades; however, its use as a seed treatment for soybean is relatively recent. Mefenoxam at $100 \mu \mathrm{g} / \mathrm{ml}$ completely inhibited the growth of most pathogenic Pythium and Phytopythium spp. including P. ultimum, one of the most aggressive species on both corn and soybean.

Ethaboxam is a newly released fungicide that is marketed specifically for its effect on oomycetes (Kim et al. 2004). In this study, it was effective against the most aggressive Pythium spp. including $P$. ultimum, $P$. irregulare, and $P$. sylvaticum, inhibiting growth at high and medium concentration levels ( 100 and $5 \mu \mathrm{g} / \mathrm{ml}$ ) by at least $97 \%$. It may be particularly effective due to its multiple modes of action (Uchida et al. 2005). Only one case of total insensitivity to the fungicide was seen in this study. Pythium acrogynum did not display any sensitivity at rates of $0.0,0.5$, or $5 \mu \mathrm{g} / \mathrm{ml}$. Treatment with $100 \mu \mathrm{g} / \mathrm{ml}$ decreased growth by only $24 \%$. However, only one isolate of $P$. acrogynum was available for testing and it is unknown if these results are representative of the species or are unique to this isolate.

Some fungicides were more effective against a single Pythium spp. than others. $P$. recalcitrans, which appeared to be relatively 
insensitive to ethaboxam, was the most sensitive of the pathogenic species to pyraclostrobin. $P$. oopapillum was least sensitive to mefenoxam but the most sensitive to trifloxystrobin. The results suggest that it is important to recognize the differences in sensitivity among Pythium spp. when considering preventative treatment options. These represent possible genetic sources of fungicide resistance within their populations. Fungicide resistance is a significant concern for growers and fungicide manufacturers; however, fungicides used as seed treatments are thought be at less risk for the development of resistance because of the low quantities used, the limited amount of time that they are active in the soil, their localized area of effect, and large background inoculum populations present in the soil that are sensitive to fungicides and would swamp resistant isolates (Brantner and Windels 1998).

Understanding the diversity, pathogenicity, and fungicide sensitivity of Pythium and Phytopythium spp. present in Minnesota soybean fields will enable producers and consultants to make more informed decisions for controlling seedling diseases caused by these organisms. Mefenoxam and ethaboxam appear to remain effective management tools in Minnesota, although decreased sensitivity or resistance has been found in other states in the North Central soybean growing region and in other cropping situations (Broders et al. 2007; Moorman and Kim 2004; Moorman et al. 2002). Another important implication of these results is the diversity of Pythium spp. and their importance as causes of soybean disease. Accurate identification of Pythium spp. prevalent in Minnesota is essential for soybean breeding programs. In general, there is little information available about sources of resistance to Pythium spp. Resistance to Pythium spp. has been identified in later maturity group (MG) soybean lines, Archer and PI 424354 (Bates et al. 2008; Rosso et al. 2008; Rupe et al. 2011). However, these lines are from later MGs, making introgression of resistance into the early MG soybean lines difficult. In addition, the resistance identified is thought to be limited to $P$. irregulare and possibly a small number of other Pythium spp. It is most likely not effective against all pathogenic Pythium spp. With the availability of molecular tools such as association mapping and the species composition information provided by this survey, breeding efforts can focus on breeding for the most commonly occurring, damaging species prevalent in Minnesota soils.

\section{Acknowledgments}

We thank the research group of M. Chilvers at Michigan State University for help with selection of Pythium isolates from seedlings that were used in this study. This was part of a large collaborative effort that will be published separately. Funding for this research was provided by the Minnesota Soybean Research and Promotion Council, The North Central Soybean Research Program, the USDA National Institute of Food and Agriculture, and The Minnesota Agricultural Experiment Station.

\section{Literature Cited}

Bala, K., Robideau, G. P., and Levesque, C. A. 2010. Phytopythium Abad, de Cock, Bala, Robideau, Lodhi \& Levesque, gen. nov. and Phytopythium sindhum Lodhi, Shahzad \& Levesque, sp. nov. Persoonia 24:136-137.

Bates, G. D., Rothrock, C. S., and Rupe, J. C. 2008. Resistance of the soybean cultivar Archer to Pythium damping-off and root rot caused by several Pythium spp. Plant Dis. 92:763-766.

Blok, I. 1973. A growth-regulating substance produced by Pythium sylvaticum. Neth. J. Plant Pathol. 79:266-276.

Brantner, J. R., and Windels, C. E. 1998. Variability in sensitivity to metalaxyl in-vitro, pathogenicity, and control of Pythium spp. on sugar beet. Plant Dis. 82:896-899.

Broders, K. D., Lipps, P. E., Paul, P. A., and Dorrance, A. E. 2007. Characterization of Pythium spp. associated with corn and soybean seed and seedling disease in Ohio. Plant Dis. 91:727-735.

Broders, K. D., Wallhead, M. W., Austin, G. D., Lipps, P. E., Paul, P. A., Mullen, R. W., and Dorrance, A. E. 2009. Association of soil chemical and physical properties with Pythium spp. diversity, community composition, and disease incidence. Phytopathology 99:957-967.

Brown, G. E., and Kennedy, B. W. 1965. Pythium pre-emergence damping-off of soybean in Minnesota. Plant Dis. Rep. 49:646.

Cohen, Y., and Coffey, M. D. 1986. Systemic fungicides and the control of oomycetes. Annu. Rev. Phytopathol. 24:311-338.

Cook, R. J., and Zhang, B.-X. 1985. Degrees of sensitivity to metalaxyl within the Pythium spp. pathogenic to wheat in the Pacific Northwest. Plant Dis. 69: 686-688. de Cock, A. W. A. M., Lodhi, A. M., Rintoul, R. L., Bala, K., Robideau, G. P., Abad, Z. G., Coffey, M. D., Shahzad, S., and Levesque, D. A. 2015. Phytopythium: Molecular phylogeny and systematics. Persoonia 34:25-39.

Dorrance, A. E., Berry, S. A., Bowen, P., and Lipps, P. E. 2004. Characterization of Pythium spp. from three Ohio fields for pathogenicity on corn and soybean and metalaxyl sensitivity. Published online. Plant Health Progress. doi:10.1094/ PHP-2004-0202-01-RS

Ellis, M. L., Paul, P., and Dorrance, A. E. 2012. Two new species of Pythium, $P$. schmitthenneri and $P$. selbyi, pathogens of corn and soybean in Ohio. Mycologia 104:477-487.

Griffin, G. J. 1990. Importance of Pythium ultimum in a disease syndrome of cv. Essex soybean. Can. J. Plant Pathol. 12:135-140.

Hardman, J. M., and Dick, M. W.1987. Short-term fluctuations in availability of Pythium propagules for isolation from soil. Trans. Br. Mycol. Soc. 88:29-39.

Hendrix, F. F., and Campbell, W. A. 1973. Pythiums as plant pathogens. Annu. Rev. Phytopathol. 11:77-98.

Holbert, J. R., Burlison, W. L., Biggar, H. H., Koehler, B., Dungan, G. H., and Jenkins, M. T. 1923. Early vigor of maize plants and yield of grain as influenced by the corn root, stalk and ear rot diseases. J. Agric. Res. 23: 583-629.

Hooker, A. L. 1956. Correlation of resistance to eight Pythium spp. in seedling corn. Phytopathology 46:175-179.

Jeffers, S. N., and Martin, S. B. 1986. Comparison of two media selective for Phytophthora and Pythium spp. Plant Dis. 70:1038-1043.

Jiang, Y. N., Haudenshield, J. S., and Hartman, G. L. 2012. Characterization of Pythium spp. from soil samples in Illinois. Can. J. Plant Pathol. 34:448-454.

Johann, H., Holbert, J. R., and Dickson, J. G. 1928. A Pythium seedling blight and root rot of dent corn. J. Agric. Res. 37:443-464.

Kim, D. S., Chun, S. J., Jeon, J. J., Lee, S. W., and Joe, G. H. 2004. Synthesis and fungicidal activity of ethaboxam against oomycetes. Pest Manag. Sci. 60: 1007-1012.

Kirkpatrick, M. T., Rupe, J. C., and Rothrock, C. S. 2006. Soybean response to flooded soil conditions and the association with soilborne plant pathogenic genera. Plant Dis. 90:592-596.

Lu, X. H., Jiang, H. H., and Hao, J. J. 2013. First report of Pythium recalcitrans causing cavity spot of carrot in Michigan. Plant Dis. 97:991.

Marchand, G., Chen, Y., Berhane, N., Wei, L., Lévesque, C. A., and Xue, A. G. 2014. Identification of Pythium spp. from the rhizosphere of soybeans in Ontario, Canada. Can. J. Plant Pathol. 36: 246-251.

Martin, F. N., and Loper, J. E. 1999. Soilborne plant diseases caused by Pythium spp.: Ecology, epidemiology, and prospects for biological control. Crit. Rev. Plant Sci. 18:111-181.

Matthiesen, R. L., Ahmad, A. A., and Robertson, A. E. 2015. Temperature affects aggressiveness and fungicide sensitivity of four Pythium spp. that cause soybean and corn damping off in Iowa. Plant Dis. 100:583-591.

Mattson, M. P. 2008. Hormesis defined. Ageing Res. Rev. 7:1-7.

Moorman, G. W., Kang, S., Geiser, D. M., and Kim, S. H. 2002. Identification and characterization of Pythium spp. associated with greenhouse floral crops in Pennsylvania. Plant Dis. 86:1227-1231.

Moorman, G. W., and Kim, S. H. 2004. Species of Pythium from greenhouses in Pennsylvania exhibit resistance to propamocarb and mefenoxam. Plant Dis. 88: 630-632.

Moralejo, E., Clemente, A., Descals, E., Belbahri, L., Calmin, G., Lefort, F., Spies, C. F., and McLeod, A. 2008. Pythium recalcitrans sp. nov. revealed by multigene phylogenetic analysis. Mycologia 100:310-319.

Murillo-Williams, A., and Pedersen, P. 2008. Early incidence of soybean seedling pathogens in Iowa. Agron. J. 100:1481-1487.

Nechwatal, J., Leiminger, J., Poschenrieder, G., and Zellner, M. 2012. Evidence for the involvement of Aphanomyces cochlioides and Pythium spp. in 'girth scab' disease of sugar beet in Bavaria. J. Plant Dis. Prot. 119:85-91.

Pegg, G. F., and Selman, I. W. 1959. An analysis of the growth response of young tomato plants to infection by Verticillium albo-atrum. Ann. Appl. Biol. 47: 222-231.

R Core Team. 2016. R: A language and environment for statistical computing. R Foundation for Statistical Computing, Vienna, Austria.

Rao, B., Schmitthenner, A. F., Caldwell, R., and Ellett, C. W. 1978. Prevalence and virulence of Pythium spp. associated with root rot of corn in poorly drained soil. Phytopathology 68:1557-1563.

Rizvi, S. S. A., and Yang, X. B. 1996. Fungi associated with soybean seedling disease in Iowa. Plant Dis. 80:57-60.

Robertson, A. E., and Ahmad, A. 2013. Nine species of Pythium associated with corn seedling blight in southeastern Iowa. Integrated Crop Management News, Iowa State University. http://crops.extension.iastate.edu/cropnews

Robideau, G. P., de Cock, A. M., Coffey, M. D., Voglmayr, H., Brouwer, H., Bala K., Chitty, D. W., Desaulniers, N., Eggertson, Q. A., Gachon, C. M. M., Hu, C.-H., Kupper, F. C., Rintoul, T. L., Sarhan, E., Verstappen, E. C. P., Zhang, Y., Bonants, P. J. M., Ristaino, J. B., and Levesque, C. A. 2011. DNA barcoding of oomycetes with cytochrome $c$ oxidase subunit I and internal transcribed spacer. Mol. Ecol. Resour. 11:1002-1011.

Rojas, A., Jacobs, J. L., Napieralski, S., Bradley, C. A., Chase, T., Esker, P. D., Giesler, L., Jardine, D., Nelson, B. D., Malvick, D., Markell, S., Robertson, A. E., Rupe, J. C., Sweets, L., Wise, K., and Chilvers, M. I. 2013. Diversity 
of oomycetes associated with soybean seedling disease in the U.S. (Abstr.) Phytopathology 103(Suppl. 2):S2.123.

Rosso, M. L., Rupe, J. C., Chen, P., and Mozzoni, L. A. 2008. Inheritance and genetic mapping of resistance to Pythium damping-off caused by Pythium aphanadermatum in 'Archer' soybean. Crop Sci. 48:2215-2222.

Rothrock, C. S., Avanzato, M. V., and Rupe, J. C. 2015. Pythium seed rot, damping-off and root rot. Pages 76-79 in: Compendium of Soybean Diseases and Pests, 5th ed. G. L. Hartman, J. C. Rupe, E. J. Sikora, L. L. Domier, J. A. Davis, and K. L. Steffey, eds. American Phytopathological Society, St. Paul, MN.

Rupe, J. C., Rothrock, C. S., Bates, G., Rosso, M. L., Avanzato, M. V., and Chen, P. 2011. Resistance to Pythium seedling disease in soybean. SoybeanMolecular Aspects of Breeding. A. Sudaric, ed. Intech, Rjeka, Croatia. doi: $10.5772 / 15301$

Schmitthenner, A. F., and Bhat, R. G. 1994. Useful methods for studying Phytophthora in the laboratory. Special Circular-Ohio Agricultural Research and Development Center.

Sprangue, R. 1943. Can we increase the yield of cereals by reducing root rot injury? Bimon. Bull. 6:20-25.

Thomson, T. B., Athow, K. L., and Laviolette, F. A. 1971. The Effect of temperature on the pathogenicity of Pythium aphanidermatum, $P$. debaryanum, and P. ultimum on soybean. Phytopathology 61:933-935.

Uchida, M., Roberson, R. W., Chun, S. J., and Kim, D. S. 2005. In vivo effects of the fungicide ethaboxam on microtubule integrity in Phytophthora infestans. Pest Manag. Sci. 61:787-792.

Wei, L., Xue, A. G., Cober, E. R., Babcock, C., Zhang, J., Zhang, S., Li, W., Wu, J., and Liu, L. 2011. Pathogenicity of Pythium spp. causing seed rot and damping-off in soybean under controlled conditions. Phytoprotection 91:3-10

Weiland, J. E., Santamaria, L., and Grunwald, N. J. 2014. Sensitivity of Pythium irregulare, $P$. sylvaticum, and $P$. ultimum from forest nurseries to mefenoxam and fosetyl-Al, and control of Pythium damping-off with fungicide. Plant Dis. 98:937-942.
White, J. G., Stanghellini, M. E., and Ayoubi, L. M. 1988. Variation in the sensitivity to metalaxyl of Pythium spp. isolated from carrot and other sources. Ann. Appl. Biol. 113:269-277.

White, T. J., Bruns, T., Lee, S., and Taylor, J. 1990. Amplification and direct sequencing of fungal ribosomal RNA genes for phylogenetics. Pages 315322 in: A Guide to Methods and Applications. T. J. White, M. A. Innis, D. H. Gelfand, and J. J. Sninsky, eds. Academic Press, New York.

Wisconsin Department of Agriculture. 2013. Trade and Consumer Protection Pythium spp. associated with soybean seedlings. Wisconsin Pest Survey Report. http://pestsurvey.wi.gov/

Wood, P. M., and Holloman, D. W. 2003. A critical evaluation of the role of alternative oxidase in the performance of strobilurin and related fungicides acting at the Qo site of complex III. Pest Manag. Sci. 59:499-511.

Wrather, J. A., and Koenning, S. R. 2009. Estimates of disease effects on soybean yields in the United States 2003 to 2005. J. Nematol. 38:173-180.

Wrather, J. A., Koenning, S. R., and Anderson, T. R. 2003. Effect of diseases on soybean yields in the United States and Ontario (1999-2002). Online. Plant Health Progress. doi:10.1094/PHP-2003-0325-01-RV

Wrather, J. A., Stienstra, W. C., and Koenning, S. R. 2001. Soybean disease loss estimates for the United States from 1996 to 1998. Can. J. Plant Pathol. 23:122-131.

Yanar, Y., Lipps, P. E., and Deep, I. W. 1997. Effect of soil saturation duration and soil water content on root rot of maize caused by Pythium arrhenomanes. Plant Dis. 81:475-80.

Yang, X. B., and Feng, F. 2001. Ranges and diversity of soybean fungal diseases in North America. Phytopathology 91:769-775.

Zhang, B. Q., Chen, W. D., and Yang, X. B. 1998. Occurrence and relative abundance of Pythium spp. in long-term maize and soybean monoculture and corn/soybean rotation fields. Mycol. Res. 102:1450-1452.

Zhang, B. Q., and Yang, X. B. 2000. Pathogenicity of Pythium populations from corn-soybean rotation fields. Plant Dis. 84:94-99.

Zitnick-Anderson, K. K., and Nelson, B. D. 2014. Identification and pathogenicity of Pythium on soybean in North Dakota. Plant Dis. 99: $31-38$ 